\title{
GROWTH PERFORMANCE, CARCASS CHARACTERISTICS AND COST OF GAIN OF AWASSI AND KARADI LAMBS SLAUGHTERED AT DIFFERENT WEIGHT
}

\author{
FATAH M. KHALAF and KHALil A. D. ORAY \\ Dept. of Animal Production,, College of Agricultural Engineering Sciences, University of Duhok \\ Kurdistan Region - Iraq
}

(Received: August 31, 2021; Accepted for Publication: November 9, 2021)

\begin{abstract}
The study was carried out to investigate the effect of slaughter weights on growth performance, carcass characteristics and cost of gain of Awassi and Karadi ram lambs. Fifteen male lambs from either Karadi or Awassi were randomly blocked by live weight into three different slaughter weight groups (30, 40 and $50 \mathrm{~kg}$ ). Each lamb was kept in individual pen and offered an iso energetic and iso nitrogenous concentrate diet ad libitum. Lambs were slaughtered once they reached a target weight.

Results reported the weight at slaughter increased for both breeds, there were significant reductions in average daily gain, bone percent, lean: fat ratio and increase in rib eye area, feed conversion ratio, fat tail weight and fat thickness. Moreover, Awassi lambs had a higher $(\mathbf{p}<0.01)$ dressing percentage 1 $(49.41 \pm 0.32 v s .47 .69 \pm 0.66 \%)$ and $2(58.32 \pm 0.45$ vs. $56.06 \pm 0.51 \%)$, fat thickness $(3.10 \pm 0.24$ vs. $2.46 \pm 0.15 \mathrm{~mm})$ and loin percentage $(8.74 \pm 0.11$ vs. $8.11 \pm 0.07 \%)$ than Karadi lambs. In contrast, Karadi lambs had a higher $(p<0.01)$ proportion of bone and lean: fat ratio and lower $(p<0.01)$ proportion of fat than Awassi lambs. There was no significant differences in daily weight gains, rib eye area, the empty body weight, fat tail weight and shrinkage percent between breeds.

In conclusion, the optimal slaughter weight is $40 \mathrm{~kg}$ for both Awassi and Karadi lambs and cost of gain of Awassi lambs was lower than Karadi lambs and from economic trends lambs slaughtered at 30kg had higher profit potential.
\end{abstract}

KEY WORD: growth, slaughter weight, carcass traits, Awassi, Karadi, Lambs

\section{INTRODUCTION}

- mall ruminant plays an important role in Iraq and it is primary for food security of the rural population and sheep population (13.025 million head) (Official Iraq Ministry of Agriculture, 2009) are account the most important farm animals and the considerable portion of income from the sale of lambs, and it has a unique niche in small farmers because small investments are required; have shorter production cycles, faster growth rates and greater environmental, adaptability as compared to large ruminants (Hashem et al., 2013). Awassi and Karadi sheep are main important indigenous Iraqi sheep primarily raised for meat (main purpose $60 \%$ ) as well as for milk and wool production 20\% (Alkass and Juma, 2005).

Awassi is the most widespread sheep breed in the Mediterranean's east. It is the most common sheep breed in Iraq and Syria, as well as the only native breed of sheep in Lebanon, Jordan and Israel (Hailat, 2005). Awassi sheep are medium in size, but the body size varies among flocks in the Middle Eastern countries (Mason, 1967; Fahmy and Shrestha, 2001), Alkass and Juma, 2005; Gursoy (2005). Moreover, Awassi has very desirable characteristics as far as endurance to nutritional variations, resistance to many diseases and parasites, walk long distances over pastures for grazing, (Gürsoy et al., 1992, 1993) and also the most important feature of these sheep is that can farmed in many sheep farms in the form of hot and dry deserts (Gürsu and Aygün, 2014).

The breed known for having the coarsest wool among Iraqi sheep breed and for it is good milking, lambing and meat potential (Juma and Alkass, 2000; Shukor, 1989).

The Karadi breed, which comprise 18-20 percent of the Iraqi sheep population, is native to the Kurdistan region of Iraq's northeastern mountains, villages, and rolling dry farming fields (Alkass et al., 2013). Also, the traditional method of fattening lambs in the Kurdistan region depends primarily on grazing natural 
pastures and cereal stubble. Sometimes, fattening of lambs depends on the barely grain and straw in feedlots, for a period of 90 to 120 days (Sadq, 2018).

Lambs body size might be a good indicator for growth performance and it could be a great trait during sheep marketing (Gizaw et al., 2010; Mtimet et al., 2014). Mtimet et al. (2014) observed that in the absence of live body weight data, breed types and visually assessed size are the most important factors in specifying the price for live animals.

Generally, daily live weight gain was decreased as lambs grew up toward heavier weight (Gohler, 1989; Chant, 1977). Sefdeen and Alkass (2009) found that the average daily live weight gain of Karadi lambs decreased over $30 \mathrm{~kg}$ slaughter body weights. Also, Oramari et al. (2014) working on Hamdani and Awassi lambs observed that heavier lambs slaughtered at $40 \mathrm{~kg}$ showed a significantly lower daily gain as compared to lambs slaughtered at $30 \mathrm{~kg}$. However, Nakev et al. (1987) concluded that daily gain in weight was increased with increasing slaughter weight in Caucasian lambs fattened until $50 \mathrm{~kg}$ after weaning. Therefore, the Objective of this study is to investigate the effect of different Slaughter weights on the growth performance, carcass characteristics and economic values of Awassi and Karadi male lambs and to find out the optimum slaughter weight.

\section{MATERIALS AND METHODS \\ 2.1. Animals and experimental procedures}

Fifteen weaned male lambs (four months age) from each of Awassi and Karadi averaged $22.46 \pm 0.26 \mathrm{~kg}$ and $22.02 \pm 0.22 \mathrm{~kg}$ in live weight, respectively, raised at the Animal Farm, Department of Animal Production, College of Agricultural Engineering Sciences, University of Duhok were used in the study. Following an adaptation period (10 days), lambs from each breed were weighed and divided in to three groups, group 1 (5 lambs from each Awassi and Karadi breeds) slaughtered at $30 \mathrm{~kg}$ live body weight, group 2 (5 lambs from each Awassi and Karadi breeds) slaughtered at $40 \mathrm{~kg}$ live body weight and group 3 (5 lambs from each Awassi and Karadi breeds) slaughtered at $50 \mathrm{~kg}$ live body weight. Lamb was raised in an individual pen $(1.50 \times 1.30 \mathrm{~m})$ and had a free access to clean water and a concentrate diet $(15.6 \%$ crude protein and $2780 \mathrm{k} . \mathrm{cal}$ ) was offered ad libitum.
Each group of lambs was offered same concentrate diet at a rate of $500 \mathrm{~g} / \mathrm{lamb} /$ day during the first 2 weeks of the trial, and then the diet was increased gradually ad libitum / lambs till slaughtering weight. The diet was offered in two equal meals at 8:00 a.m. and 4:00 p.m. The diet ingredients included $46 \%$ barley, $10 \%$ corn, $14 \%$ wheat bran, $10 \%$ wheat straw, $17 \%$ soybean meal, $2 \% \mathrm{CaCo3}, 0.4 \%$ di-Calcium Phosphate, $0.5 \%$ salt and $0.5 \%$ multivitamin. The chemical composition of the concentrate ration contained $15.6 \%$ crude protein, $5.5 \%$ crude fiber, $3.6 \%$ ether extract, $4.9 \%$ ash and 2780 k.cal energy.

\subsection{Slaughter and carcass traits}

The day before lambs were slaughtered, lambs were weighed, restricted from a diet and had a free access to water. Following slaughter, hot carcass weight, cold carcass weight (after chilling at $2-4^{\circ} \mathrm{C}$ for 24 hours) were recorded using a portable electronic scale (capacity $50 \mathrm{~kg}$ ). After chilling the carcass at $2-4^{\circ} \mathrm{C}$ for 24 hours, chilled carcass was weighted, and then kidney, pelvic and heart fat were removed and weighted separately, by using an electrical saw the carcass was divided along the vertebral column into left and right halves. The right half was separated into eight commercial cuts (leg, shoulder, loin, rack, fore shank, neck, breast and flank). Each cut of right half was weighed and calculated as a percent of cold carcass weight. Ribeye area was evaluated between the 12 "'and 13 "'ribs, on the cross-section by tracing the longissumus dorsi muscle upon waxed paper, and the area was measured by a placom digital planimeter KP $92 \mathrm{~N}$. Fat thickness over the longissimu dorsi perpendicularly was taken by using Calliper device. In order to determine carcass composition each cuts of the right half were dissected physically into lean, fat and bone then lean to fat ratio and lean to bone ratio were calculated.

\subsection{Chemical analysis}

To determine the chemical analysis (protein, extract fat, moisture, and ash), the homogenous samples of meat from longissimus dorsi muscle was collected from each carcass by using standard methods (AOAC, 1990). Crude protein was determined as $(\mathrm{N} \times 6.25)$ (Kjeldahl method).

\subsection{Statistical Analysis}

Data was analyzed as factorial $2 \times 3$ (breed and slaughter weight) using a general leaner model (SAS, 2002), to study the impact of unbiased of the breed and slaughter weight on 
two studies traits. The differences among the subclass of each factor were tested by using Duncan multiple range tests (1955) within GLM by using SAS (2002).

\section{RESULTS AND DISCUSSION 3.1. Growth performance}

The effect of slaughter weight and breeds on lamb performance is presented in Table (1). The average daily gain of Awassi lambs was $0.219 \pm 0.02 \mathrm{~kg} /$ day, whereas for Karadi lambs was $0.212 \pm 0.06 \mathrm{~kg} /$ day. However, the difference in daily weight gain between two breeds was not significant. In contrast to the previous result, Alkass et al. (1985); Alkass et al. (1987); Rashid et al. (1987); Al-Jaryan et al. (1995); Esenbuga et al. (2009); Sefdeen and Alkass (2009); Oramari et al. (2014); Jawasreh et al. (2019); Suliman et al. (2021) reported that Awassi and Karadi lambs had a higher average daily gain. Whereas, Macit et al. (2002) and Dosky et al. (2014) recorded a lower average daily gain. Such a results could be related to the genetic of the lambs as well as different nutrition practice in particular. A significant difference $(p<0.01)$ in daily gain was noticed among lambs slaughtered at $(30,40$ and $50 \mathrm{~kg})$ with highest gain $(0.282 \pm 0.07 \mathrm{~kg} /$ day $)$ for lambs slaughtered at $30 \mathrm{~kg}$ and lowest $(0.162 \pm 0.01 \mathrm{~kg} /$ day $)$ for lambs slaughtered at $50 \mathrm{~kg}$. The depression in average daily gain of lambs slaughtered at heavier weight (more than $40 \mathrm{~kg}$ ) as noticed in this study may be due to accumulation of fat tissue and that as average daily gain, favors a leaner animal since the feed efficiency to produce lean tissue gain is greater than for fat tissue gain (Rashid et al., 1987; Aksoy., 1995; Balci and Karakas, 2007; Sefdeen and Alkass, 2009).

\subsection{Feed Efficiency}

It seems that, the differences between feed conversion ratio and feed efficiency were significant between two breeds, the Awassi lambs had significantly $(\mathrm{p}<0.01)$ better feed conversion ratio and feed efficiency as compared to Karadi lambs. The average feed conversion ratio noticed in the present work for Awassi lambs was lower than to those previously recorded for Awassi lambs (Esenbuga et al., 2009; Suliman et al., 2021) as well as for Karadi lambs (Dosky et al., 2014) and higher than to those reported by (Oramari et al., 2014; Jawasreh et al., 2019) for Awassi lambs and Sefdeen and Alkass (2009), for Karadi lambs. However, Gootwine et al. (1993) and Rodríguez et al. (2011) who observed that feed efficiency were improved significantly in crossbreed. Such differences among breeds could be due to genetic, age of animal, quality of feed and management practice used on the farm, Karadi lambs showed greater daily feed consumption than Awassi lambs. Also, lambs slaughtered at $30 \mathrm{~kg}$ had significantly $(\mathrm{p}<0.01)$ preferable feed conversion ratio and feed efficiency as compared to lambs slaughtered at $50 \mathrm{~kg}$. This reduction possibly due to deposition of more fat in lambs slaughtered at heavier weights (Oramari et al., 2014). Such result was in agreement with Shelton and Carpenter (1972), Sents et al. (1982) and Sefdeen and Alkass (2009).

Table (1): Fattening performance traits of Karadi and Awassi lambs.

\begin{tabular}{|c|c|c|c|c|c|c|}
\hline \multirow[t]{2}{*}{ Traits } & \multirow{2}{*}{$\begin{array}{l}\text { Overall } \\
\text { mean }\end{array}$} & \multicolumn{2}{|c|}{ Breed } & \multicolumn{3}{|c|}{ Slaughter weight (kg) } \\
\hline & & Karadi & Awassi & 30 & 40 & 50 \\
\hline Animal No. & 28 & 13 & 15 & 10 & 9 & 9 \\
\hline Initial live weight (kg) & $22.23 \pm 0.17$ & $22.46 \pm 0.26 a$ & $22.02 \pm 0.22 a$ & $21.91 \pm 0.28 a$ & $22.38 \pm 0.29 a$ & $22.43 \pm 0.32 a$ \\
\hline Final live weight (kg) & $40.08 \pm 1.52$ & $39.89 \pm 2.30 a$ & $40.25 \pm 2.10 a$ & $31.00 \pm 0.17 c$ & $40.05 \pm 0.20 b$ & $50.20 \pm 0.14 a$ \\
\hline Total weight gain $(\mathrm{kg})$ & $17.85 \pm 1.49$ & $17.43 \pm 2.27 a$ & $18.22 \pm 2.03 a$ & $9.09 \pm 0.23 c$ & $17.64 \pm 0.39 \mathrm{~b}$ & $27.77 \pm 0.34 a$ \\
\hline Days to slaughter & $\begin{array}{c}97.68 \pm 11.9 \\
7 \\
\end{array}$ & $98.31 \pm 18.84 a$ & $97.13 \pm 15.89 a$ & $32.20 \pm 0.33 c$ & $91.44 \pm 4.13 b$ & $176.67 \pm 10.39 a$ \\
\hline $\begin{array}{l}\text { Daily weight gain } \\
\text { (kg/day) }\end{array}$ & $0.216 \pm 0.01$ & $0.212 \pm 0.06 a$ & $0.219 \pm 0.02 a$ & $0.282 \pm 0.07 a$ & $0.196 \pm 0.01 b$ & $0.162 \pm 0.01 \mathrm{c}$ \\
\hline Total feed intake (kg) & $\begin{array}{c}95.85 \pm 10.6 \\
7 \\
\end{array}$ & $99.63 \pm 17.49 a$ & $92.59 \pm 13.46 a$ & $32.39 \pm 0.50 \mathrm{c}$ & $98.44 \pm 4.54 b$ & $163.78 \pm 6.19 a$ \\
\hline Daily feed intake (kg/day) & $1.011 \pm 0.02$ & $1.043 \pm 0.04 a$ & $0.984 \pm 0.03 a$ & $1.006 \pm 0.01 \mathrm{ba}$ & $1.081 \pm 0.04 a$ & $0.948 \pm 0.06 b$ \\
\hline Feed conversion $(\mathrm{kg} / \mathrm{kg})$ & $4.97 \pm 0.23$ & $5.22 \pm 0.36 a$ & $4.75 \pm 0.29 b$ & $3.58 \pm 0.09 b$ & $5.58 \pm 0.25 a$ & $5.90 \pm 0.24 a$ \\
\hline Feed efficiency (kg/kg) & $0.214 \pm 0.01$ & $0.204 \pm 0.02 b$ & $0.223 \pm 0.01 \mathrm{a}$ & $0.281 \pm 0.01 a$ & $0.183 \pm 0.01 b$ & $0.172 \pm 0.01 b$ \\
\hline
\end{tabular}

Means with different letters within each column for Karadi and Awassi male lambs differ significantly $(\mathrm{P}<0.01)$ according to Duncan's test. 


\subsection{Carcass characteristics}

The results related to slaughter traits (empty body weight, shrinkage percent, dressing percentage, carcass weight and fat tail weight) of different slaughter weights for Awassi and Karadi lambs are given in (Table 2). Dressing percentage 1(based on slaughter weight) and 2 (based on empty body weight) were significantly higher than Karadi lambs. This finding is similar to results observed that dressing percentage was significantly different among studied breeds (Alkass et al., 1987; Snowder et al., 1994; Cloete et al., 2004; Kashan et al., 2005; Ríos et al., 2011). The empty body weight, fat tail weight and shrinkage percent for Awassi lambs were averaged $(34.13 \pm 1.74 \mathrm{~kg}, \quad 2.91 \pm 0.36 \mathrm{~kg}$ and $2.62 \pm 0.15 \%$ ), respectively and for Karadi lambs were averaged $(33.84 \pm 2.10 \mathrm{~kg}, 2.61 \pm 0.3 \mathrm{~kg}$ and $2.81 \pm 0.17 \%$ ), respectively (Table 2), none significant differences were observed between Awassi and Karadi lamb breeds for above traits. It was found that deference in the dressing percentage 1 and 2 between lambs slaughtered at
$30,40 \mathrm{~kg}$ lacked significance. This result is similar to the finding of Oramari et al. (2014) who concluded that as slaughter weight increases, dressing percentage decreased from 30 to $40 \mathrm{~kg}$ of slaughter weight. While, lambs slaughtered at $50 \mathrm{~kg}$ significantly had higher dressing percentages 1and 2 as compared to lambs were slaughtered at $40 \mathrm{~kg}$. Similar results has been reported by Bicer et al. (1995) who noticed that dressing percentages was significantly increased from 40 to $50 \mathrm{~kg}$ of body live weight, where after, it remained almost constant. Also, same results were concluded by several authors (Lambuth et al., 1970; Lloyd et al., 1980; Sefdeen and Alkass, 2009; Polidori et al., 2017). While, some researcher approved that dressing percentage was decreased as slaughter weight increased (Jeremiah et al., 1997; Oramari et al., 2014). The shrinkage percent was significantly $(\mathrm{p}<0.01)$ decreased with increasing slaughter weight from 30 to $50 \mathrm{~kg}$ of body weight.

Table (2): The effect of breed and different slaughter weights on some carcass characteristics of Karadi and Awassi lambs (Means \pm S.E.).

\begin{tabular}{|c|c|c|c|c|c|c|}
\hline \multirow[t]{2}{*}{ Traits } & \multirow{2}{*}{$\begin{array}{l}\text { Overall } \\
\text { mean }\end{array}$} & \multicolumn{2}{|c|}{ Breed } & \multicolumn{3}{|c|}{ Slaughter weight (kg) } \\
\hline & & Karadi & Awassi & 30 & 40 & 50 \\
\hline Animal No. & 28 & 13 & 15 & 10 & 9 & 9 \\
\hline Slaughter weight $(\mathrm{kg})$ & $40.08 \pm 1.52$ & $39.89 \pm 2.30 a$ & $40.25 \pm 2.10 a$ & $31.00 \pm 0.17 \mathrm{c}$ & $40.05 \pm 0.20 \mathrm{~b}$ & $50.20 \pm 0.14 a$ \\
\hline $\begin{array}{c}\text { Hot carcass weight } \\
(\mathrm{kg})\end{array}$ & $19.49 \pm 0.79$ & $18.99 \pm 1.22 b$ & $19.92 \pm 2.10 \mathrm{a}$ & $14.97 \pm 0.29 \mathrm{c}$ & $19.19 \pm 0.20 \mathrm{~b}$ & $24.82 \pm 0.28 a$ \\
\hline $\begin{array}{c}\text { Chilled carcass weight } \\
(\mathrm{kg})\end{array}$ & $18.98 \pm 0.79$ & $18.48 \pm 1.21 b$ & $19.42 \pm 1.07 a$ & $14.48 \pm 0.29 \mathrm{c}$ & $18.67 \pm 0.20 \mathrm{~b}$ & $24.30 \pm 0.29 a$ \\
\hline $\begin{array}{c}\text { Empty body weight } \\
(\mathrm{kg})\end{array}$ & $33.99 \pm 1.33$ & $33.84 \pm 2.10 \mathrm{a}$ & $34.13 \pm 1.74 a$ & $26.07 \pm 0.23 c$ & $34.12 \pm 0.20 \mathrm{~b}$ & $42.68 \pm 0.45 a$ \\
\hline Shrinkage (\%) & $2.71 \pm 0.11$ & $2.81 \pm 0.17 a$ & $2.62 \pm 0.15 a$ & $3.23 \pm 0.13 a$ & $2.74 \pm 0.07 \mathrm{~b}$ & $2.10 \pm 0.14 \mathrm{c}$ \\
\hline $\begin{array}{c}\text { Dressing percentage } \\
\text { (1) }\end{array}$ & $48.61 \pm 0.38$ & $47.69 \pm 0.66 b$ & $49.41 \pm 0.32 a$ & $48.31 \pm 0.82 a b$ & $47.88 \pm 0.44 b$ & $49.68 \pm 0.51 a$ \\
\hline $\begin{array}{c}\text { Dressing percentage } \\
\text { (2) }\end{array}$ & $57.27 \pm 0.40$ & $56.06 \pm 0.51 b$ & $58.32 \pm 0.45 a$ & $57.37 \pm 0.73 a b$ & $56.26 \pm 0.54 b$ & $58.18 \pm 0.69 a$ \\
\hline $\begin{array}{c}\text { Fat tail weight } \\
(\mathrm{kg})\end{array}$ & $2.77 \pm 0.24$ & $2.61 \pm 0.31 a$ & $2.91 \pm 0.36 a$ & $1.67 \pm 0.09 c$ & $2.44 \pm 0.13 b$ & $4.33 \pm 0.27 a$ \\
\hline
\end{tabular}

Means with different letters within each column for Karadi and Awassi male lambs differ significantly $(\mathrm{P}<0.01)$ according to Duncan's test.

\subsection{Rib eye area and Fat thickness}

The effects of breeds and slaughter weight on rib eye area and fat thickness are presented in Table (3). The differences between rib eye area was non-significant between two breeds, the result obtained in the current study was in an agreement with the results noticed by Snowder et al. (1994) who noticed a not significant difference in rib eye muscle area among Rambouillet, Targhee, Columbia and polypay lambs. Also, Lloyd et al. (1980); Kashan et al. (2005) and Esenbuga et al. (2009) found that breed does not significantly impact the rib eye area. Similarly, Oramari et al. (2014) indicated that rib eye muscle area was not differ significantly between Hamdani and Awassi breed $\left(11.47\right.$ vs. $\left.11.52 \mathrm{~cm}^{2}\right)$. On the other hand, Macit (2002) and Jawasreh et al. (2019) found that a significant differences in rib eye area among studied breeds While, the Awassi lambs had significantly thicker fat over the rib eye muscle as compared to Karadi lambs (Table 3). Similarly, Lloyd et al. (1980), Snowder et al. (1994), Kashan et al. (2005) and Oramari et al. 
(2014) found that fat thickness was significantly impacted by breed. In contrast, Macit (2002), Esenbuga et al. (2009) and Jawasreh et al. (2019) found that fat thickness over dorsi muscle not significantly affected among different breeds of lamb.

It seems that, Rib eye area was expanded significantly $(p<0.01)$ by increasing slaughter weights. The lambs slaughtered at $30 \mathrm{~kg}$ had a significantly lower fat thickness $(\mathrm{p}<0.01)$ as compared to lambs 40 and $50 \mathrm{~kg}$. While no significant differences approved between lambs slaughtered at 40 to $50 \mathrm{~kg}$ (Table 3). This result was supported by those reported by Sents et al.
(1982), Rashid et al. (1987), Macit (2002), Balci and Karakas (2007), Abdullah and Qudsieh (2008), Sefdeeen and Alkass (2009), Oramari et al. (2014) and Aksoy and Ulutaş (2015) who revealed that, rib eye area become more expanded and thicker fat over rib eye muscle when the slaughter weight increased. Adversely, (Rajkumar and Agnihotri 2005; Das et al., 2008 and Rajkumar et al., 2014) approved nonsignificant impact of slaughter weight on fat thickness and rib eye muscle area when carcass characteristics were studied under the effect of slaughter weight.

Table (3): The effect of breed and different slaughter weights on rib eye area, fat thickness and body wall thickness of Karadi and Awassi lambs (Means \pm S.E.).

\begin{tabular}{|c|c|c|c|c|c|c|}
\hline \multirow[t]{2}{*}{ Traits } & \multirow{2}{*}{$\begin{array}{c}\text { Overall } \\
\text { mean }\end{array}$} & \multicolumn{2}{|c|}{ Breed } & \multicolumn{3}{|c|}{ Slaughter weight (kg) } \\
\hline & & Karadi & Awassi & 30 & 40 & 50 \\
\hline Animal No. & 28 & 13 & 15 & 10 & 9 & 9 \\
\hline Rib eye area $\left(\mathrm{cm}^{2}\right)$ & $\begin{array}{c}11.72 \pm 0.3 \\
0\end{array}$ & $11.61 \pm 0.50 \mathrm{a}$ & $11.82 \pm 0.38 a$ & $10.39 \pm 0.29 \mathrm{c}$ & $11.86 \pm 0.38 b$ & $13.07 \pm 0.50 \mathrm{a}$ \\
\hline Fat thickness (mm) & $2.80 \pm 0.16$ & $2.46 \pm 0.15 b$ & $3.10 \pm 0.24 a$ & $2.10 \pm 0.15 b$ & $2.96 \pm 0.21 \mathrm{a}$ & $3.43 \pm 0.26 a$ \\
\hline
\end{tabular}

\subsection{Physical dissection (carcass tissue distribution)}

It appears from the result presented in Table (4) that lean proportion was not different significantly between the two breeds. While, the Awassi lambs significantly $(\mathrm{p}<0.01)$ recorded higher fat $\%$, lean: bone ratio and lowest bone $\%$, lean: fat ratio as compared to Karadi lambs (Table 4). The differences between these two breeds is in accordance with the results obtained by Several authors found that breed affects the carcass tissue distribution in studied sheep breeds (Kashan et al., 2005; Rodríguez et al., 2011; Oramari et al., 2014).

Lambs carcasses slaughtered at $40 \mathrm{~kg}$ significantly $(\mathrm{p}<0.01)$ leaner as compared to carcasses of lambs slaughtered at $50 \mathrm{~kg}$. It appears from the result that lean tissue, increase by increasing slaughter weight till $40 \mathrm{~kg}$ live weight then decreased by increase weight up to $50 \mathrm{~kg}$. Also, lamb carcasses slaughtered at $40 \mathrm{~kg}$ live weight approved significantly $(\mathrm{p}<0.01)$ more lean to bone ratio as compared to carcasses of lambs slaughtered at 30 and $50 \mathrm{~kg}$ and significantly more lean to fat ratio than lambs slaughtered at $50 \mathrm{~kg}$ live weight. On the same line, Bicer et al. (1995) noticed that carcasses of Awassi lambs slaughtered at $40 \mathrm{~kg}$ had significantly more lean percent compare to lambs slaughtered at 50,60 and $65 \mathrm{~kg}$ live weight. However, with increasing slaughter weight, fat proportion changed significantly from 40 to $50 \mathrm{~kg}$ live weight, but not significantly from 30 to $40 \mathrm{~kg}$. Similar finding has been reported by (Bicer et al., 1995; Abdullah and Qudsieh, 2008; Sefdeen and Alkass, 2009; Aksoy and Ulutaş, 2015). 
Table (4): The effect of breed and different slaughter weights on dissected lean, fat and bone of

Karadi and Awassi lambs (Means \pm S.E.).

Means with different letters within each column for Karadi and Awassi male lambs differ significantly $(\mathrm{P}<0.01)$

\begin{tabular}{|c|c|c|c|c|c|c|}
\hline \multirow[t]{2}{*}{ Traits } & \multirow{2}{*}{$\begin{array}{c}\text { Overall } \\
\text { mean }\end{array}$} & \multicolumn{2}{|c|}{ Breed } & \multicolumn{3}{|c|}{ Slaughter weight (kg) } \\
\hline & & Karadi & Awassi & 30 & 40 & 50 \\
\hline Animal No. & 28 & 13 & 15 & 10 & 9 & 9 \\
\hline Lean \% & $58.67 \pm 0.62$ & $59.21 \pm 0.68 a$ & $58.20 \pm 1.00 a$ & $58.77 \pm 0.61 \mathrm{ba}$ & $60.76 \pm 0.93 a$ & $56.48 \pm 1.24 \mathrm{~b}$ \\
\hline Fat \% & $19.66 \pm 0.71$ & $17.80 \pm 0.86 \mathrm{~b}$ & $21.28 \pm 0.93 a$ & $17.68 \pm 0.91 \mathrm{~b}$ & $19.20 \pm 0.84 b$ & $22.32 \pm 1.45 a$ \\
\hline Bone \% & $21.72 \pm 11.94$ & $23.08 \pm 0.55 a$ & $20.54 \pm 0.65 b$ & $23.55 \pm 0.77 a$ & $20.13 \pm 0.94 b$ & $21.27 \pm 0.31 b$ \\
\hline Lean: fat ratio & $3.11 \pm 0.13$ & $3.44 \pm 0.19 a$ & $2.83 \pm 0.16 \mathrm{~b}$ & $3.41 \pm 0.20 a$ & $3.22 \pm 0.16 a$ & $2.66 \pm 0.27 b$ \\
\hline Lean: bone ratio & $2.74 \pm 0.08$ & $2.58 \pm 0.66 b$ & $2.88 \pm 0.12 a$ & $2.52 \pm 0.09 \mathrm{~b}$ & $3.08 \pm 0.17 a$ & $2.66 \pm 90.04 b$ \\
\hline
\end{tabular}

according to Duncan's test.

\subsection{Commercial cuts of the carcass}

The effects of breeds and slaughter weights on commercial cuts of the carcass are presented in Table (5), with the exception of leg and loin proportion, none of the commercial cuts were impacted significantly by breed of lambs (Table 5). It seems from result that Karadi lambs recorded significantly higher proportion of leg $(34.72 \pm 0.51$ vs. $32.01 \pm 0.40 \%)$ and lowest proportion of loin $(8.11 \pm 0.07$ vs. $8.74 \pm 0.11 \%)$ as compared to Awassi lambs. Therefore, loin, Leg, and rack cuts are predestined more worthy by industry standards (Cameron et al., 2001). These commercial cuts comprise nearly $60 \%$ of lamb carcass (Hale and Griffin, 1992). Moreover, several authors approved significant differences were observed in wholesale cuts among breeds (Fahmy, 1997; Hopkins and Fogarty, 1998; Macit et al., 2002; Kashan et al., 2005; Oramari et al., 2014). Similarly, significant variable between Tushin and Awassi lamb breeds were observed in carcass cuts by Bicer et al. (1995).
It seems from Table (5) that no differences exist in the Leg, Shoulder, Loin, Breast and neck among lambs slaughtered at 30, 40 and $50 \mathrm{~kg}$. While, the heavier lambs slaughtered at $50 \mathrm{~kg}$ recorded significantly higher percent of rack and lower percent of fore shank than those slaughters at 30 and $40 \mathrm{~kg}$. But, the lambs slaughtered $30 \mathrm{~kg}$ appeared significantly higher proportion of flank than those slaughters at 40 and $50 \mathrm{~kg}$ are presented in Table (5). The differences among slaughter weighs are in accordance with the results obtained by Several authors who found that the slaughter weigh affects the some commercial cuts of the carcass in studied sheep breeds (Kemp et al. 1981; Sents et al., 1982; Balci and Karakaş, 2007; Abdullah and Qudsieh, 2008; Sefdeen and Alkass, 2009; Oramari et al., 2014; Aksoy and Ulutaş, 2015). Though, such changes reveal the different rates of maturity among the commercial cuts of the carcass previously reported by Pálsson and Verges (1952) that leg mature relatively early and the neck and loin are later maturing regions. 
Table (5): The effect of breed and different slaughter weights on the proportion wholesale cuts of Karadi and Awassi lambs (Means \pm S.E.).

\begin{tabular}{ccccccc}
\hline Traits & $\begin{array}{c}\text { Overall } \\
\text { mean }\end{array}$ & \multicolumn{3}{c}{ Breed } & \multicolumn{3}{c}{ Slaughter weight (kg) } \\
\cline { 3 - 7 } & & Karadi & Awassi & 30 & 40 & 50 \\
\hline Animal No. & $\mathbf{2 8}$ & $\mathbf{1 3}$ & $\mathbf{1 5}$ & $\mathbf{1 0}$ & $\mathbf{9}$ & $\mathbf{9}$ \\
\hline Leg \% & $33.27 \pm 0.41$ & $34.72 \pm 0.51 \mathrm{a}$ & $32.01 \pm 0.40 \mathrm{~b}$ & $33.59 \pm 0.64 \mathrm{a}$ & $33.58 \pm 0.81 \mathrm{a}$ & $32.60 \pm 0.70 \mathrm{a}$ \\
\hline Shoulder \% & $19.01 \pm 0.40$ & $18.98 \pm 0.65 \mathrm{a}$ & $19.04 \pm 0.48 \mathrm{a}$ & $18.28 \pm 0.57 \mathrm{a}$ & $19.03 \pm 0.89 \mathrm{a}$ & $19.81 \pm 0.51 \mathrm{a}$ \\
\hline Rack \% & $9.15 \pm 0.21$ & $8.95 \pm 0.34 \mathrm{a}$ & $9.32 \pm 0.26 \mathrm{a}$ & $8.87 \pm 0.30 \mathrm{~b}$ & $8.48 \pm 0.37 \mathrm{~b}$ & $10.14 \pm 0.14 \mathrm{a}$ \\
\hline Loin \% & $8.45 \pm 0.09$ & $8.11 \pm 0.07 \mathrm{~b}$ & $8.74 \pm 0.11 \mathrm{a}$ & $8.37 \pm 0.15 \mathrm{a}$ & $8.45 \pm 0.12 \mathrm{a}$ & $8.54 \pm 0.20 \mathrm{a}$ \\
\hline Breast \% & $9.04 \pm 0.17$ & $8.95 \pm 0.27 \mathrm{a}$ & $9.11 \pm 0.22 \mathrm{a}$ & $8.87 \pm 0.30 \mathrm{a}$ & $9.15 \pm 0.29 \mathrm{a}$ & $9.10 \pm 0.32 \mathrm{a}$ \\
\hline Fore shank\% & $7.33 \pm 0.23$ & $7.51 \pm 0.41 \mathrm{a}$ & $7.17 \pm 0.26 \mathrm{a}$ & $7.32 \pm 0.27 \mathrm{ba}$ & $7.98 \pm 0.51 \mathrm{a}$ & $6.68 \pm 0.35 \mathrm{~b}$ \\
\hline Neck \% & $6.62 \pm 0.28$ & $6.14 \pm 0.41 \mathrm{a}$ & $7.03 \pm 0.36 \mathrm{a}$ & $7.13 \pm 0.50 \mathrm{a}$ & $6.55 \pm 0.55 \mathrm{a}$ & $6.12 \pm 0.38 \mathrm{a}$ \\
\hline Flank\% & $7.24 \pm 0.16$ & $7.04 \pm 0.26 \mathrm{a}$ & $7.42 \pm 0.20 \mathrm{a}$ & $7.86 \pm 0.16 \mathrm{a}$ & $6.78 \pm 0.30 \mathrm{~b}$ & $7.02 \pm 0.27 \mathrm{~b}$ \\
\hline
\end{tabular}

Means with different letters within each column for Karadi and Awassi male lambs differ significantly $(\mathrm{P}<0.01)$ according to Duncan's test.

\subsection{Portioning of fat}

Fat content in the body of Awassi and Karadi sheep expressed as proportion from total body fat are presented in the Table (6). Carcass fat and non-carcass fat of Awassi lambs were $(60.78 \pm 1.93 \%$ and $39.22 \pm 1.93 \%)$ respectively, whereas for Karadi lambs were $(57.92 \pm 2.42 \%$ and $42.08 \pm 2.42 \%$ ) respectively. However, the differences in Carcass fat and non-carcass fat between two breeds was not significant. Moreover, among non-carcass fat for Awassi and Karadi lambs, omental and mesenrtic fat had the highest $(\mathrm{P}$ value) percent $(66.42 \pm 1.24$ and $69.20 \pm 2.46 \%$ ) respectively, followed by kidney and pelvic fat $(25.25 \pm 1.07$ and $21.35 \pm 1.83 \%)$, respectively and cardiac fat $(8.33 \pm 0.75$ and $9.46 \pm 1.00 \%$ ), respectively (Table 7 ). Percentage of total body fat from the right side of carcass weight was not significantly affected by lambs breeds. Moreover, among non-carcass fat Awassi lambs significantly had a more proportion of kidney and pelvic fat $(25.25 \pm 1.07 \%)$ as compared to Karadi lambs $(21.35 \pm 1.83 \%)$. These results disagree with the results of Oramari et al. (2014) reviewed that significant difference was observed in percentages for the portioning of fat for studying breeds, who reported that Awassi lambs deposited more carcass fat and non-carcass fat as compared to Hamdani lambs.

In the current work, total body fat was significantly increased with increasing slaughter body weight from 30 to $50 \mathrm{~kg}$ of body weight (Table 6). It appears from the result that lambs grew up toward heavier weight percent of carcass fat significantly decreased and the percent of non-carcass fat increased. This result confirms those of Sefdeen and Alkass (2009) who found when lambs enlarged in weight recorded significantly more percent of noncarcass 
Table (6): The effect of breed and different slaughter weights on partitioning of fat of Karadi and Awassi lambs (Means \pm S.E.).

\begin{tabular}{|c|c|c|c|c|c|c|}
\hline \multirow[t]{2}{*}{ Traits } & \multirow{2}{*}{$\begin{array}{l}\text { Overall } \\
\text { mean }\end{array}$} & \multicolumn{2}{|c|}{ Breed } & \multicolumn{3}{|c|}{ Slaughter weight (kg) } \\
\hline & & Karadi & Awassi & 30 & 40 & 50 \\
\hline Animal No. & 28 & 13 & 15 & 10 & 9 & 9 \\
\hline Total Fat $(\mathrm{kg})$ & $2.79 \pm 0.22$ & $2.63 \pm 0.40 a$ & $2.92 \pm 0.25 a$ & $1.67 \pm 0.09 \mathrm{c}$ & $2.65 \pm 0.12 b$ & $4.16 \pm 0.31 a$ \\
\hline Carcass Fat \% & $59.45 \pm 1.53$ & $57.92 \pm 2.42 a$ & $60.78 \pm 1.93 a$ & $66.05 \pm 0.77 a$ & $57.85 \pm 2.12 b$ & $53.71 \pm 2.95 b$ \\
\hline Non-Carcass Fat \% & $40.55 \pm 1.53$ & $42.08 \pm 2.42 a$ & $39.22 \pm 1.93 a$ & $33.95 \pm 0.77 \mathrm{~b}$ & $42.15 \pm 2.12 a$ & $46.29 \pm 2.95 a$ \\
\hline Kidney and Pelvic Fat & $23.44 \pm 1.07$ & $21.35 \pm 1.83 b$ & $25.25 \pm 1.07 a$ & $27.53 \pm 0.91 \mathrm{a}$ & $20.72 \pm 1.54 b$ & $21.61 \pm 2.24 \mathrm{~b}$ \\
\hline $\begin{array}{c}\text { Omental and } \\
\text { Mesenrtic Fat \% }\end{array}$ & $67.71 \pm 1.32$ & $69.20 \pm 2.46 a$ & $66.42 \pm 1.24 a$ & $62.14 \pm 1.45 b$ & $70.70 \pm 1.78 \mathrm{a}$ & $70.90 \pm 2.40 a$ \\
\hline Cardiac Fat $\%$ & $8.85 \pm 0.61$ & $9.46 \pm 1.00 a$ & $8.33 \pm 0.75 a$ & $10.33 \pm 1.08 a$ & $8.58 \pm 1.07 a$ & $7.50 \pm 0.89 a$ \\
\hline
\end{tabular}

Means with different letters within each column for Karadi and Awassi male lambs differ significantly $(\mathrm{P}<0.01)$ according to Duncan's test.

\subsection{Chemical composition}

Chemical composition of the logissmus dorsi muscle of Awassi and Karadi lambs slaughtered at 30,40 and $50 \mathrm{~kg}$ are shown in Table (7). None significant differences were observed between Awassi and Karadi lamb breeds for (moisture, protein, fat and ash traits) (Table 7). In the term of the impact of breed on meat protein, moisture and fat the results are in accordance with the finding of Suliman et al. (2021). On the other hand, this finding disagree with the results of Kashan et al. (2005) and Esenbuğa et al. (2009) who noticed that the chemical composition of meat samples, especially for moisture, protein and fat percent were significantly affected by the breed of lambs.

The moisture content of lamb meat was decreased significantly when lambs grew up toward heavier weight (Table 7). Lambs slaughtered at $50 \mathrm{~kg}$ live weight recorded significantly lower moisture percent as compared to lambs slaughtered at $40 \mathrm{~kg}$ and $30 \mathrm{~kg}$. Also, there were significant differences among slaughtere weight for protein percent for lambs slaughtered at $50 \mathrm{~kg}$ as compared to lambs slaughtered at 40 and $30 \mathrm{~kg}$. Additionally, fat percent increased significantly with increasing slaughter weight from $30 \mathrm{~kg}$ to $50 \mathrm{~kg}$ live weight. While, no significant difference was found in ash percent among slaughter weights. This result was similar to those reported by Das et al. (2008), Abdullah and Qudsieh (2008) and Rajkumar et al. (2014) who approved that the fat content of rib eye muscle increased and moisture content decreased with increasing slaughter weights and also Sen et al. (2004) and Polidori et al. (2017) examined that older animals revealed significantly more depots of lipid and higher content of protein compared to lambs slaughtered at a younger age.

Table (7): Chemical composition of meat samples of Karadi and Awassi lambs slaughtered at different slaughter weights (Means \pm S.E.).

\begin{tabular}{|c|c|c|c|c|c|c|}
\hline \multirow[t]{2}{*}{ Traits } & \multirow{2}{*}{$\begin{array}{l}\text { Overall } \\
\text { mean }\end{array}$} & \multicolumn{2}{|c|}{ Breed } & \multicolumn{3}{|c|}{ Slaughter weight (kg) } \\
\hline & & Karadi & Awassi & 30 & 40 & 50 \\
\hline Animal No. & 28 & 13 & 15 & 10 & 9 & 9 \\
\hline Moisture \% & $74.67 \pm 0.35$ & $74.52 \pm 0.58 a$ & $74.80 \pm 0.43 a$ & $76.68 \pm 0.12 a$ & $74.40 \pm 0.32 b$ & $72.72 \pm 0.32 \mathrm{c}$ \\
\hline Dry mater \% & $25.17 \pm 0.39$ & $25.40 \pm 0.66 a$ & $24.97 \pm 0.46 a$ & $22.85 \pm 0.12 \mathrm{c}$ & $25.79 \pm 0.44 b$ & $27.12 \pm 0.29 a$ \\
\hline Protein \% & $19.71 \pm 0.20$ & $19.93 \pm 0.37 a$ & $19.52 \pm 0.20 \mathrm{a}$ & $18.74 \pm 0.23 \mathrm{c}$ & $19.77 \pm 0.20 \mathrm{~b}$ & $20.73 \pm 0.25 a$ \\
\hline Fat $\%$ & $4.15 \pm 0.23$ & $3.94 \pm 0.33 a$ & $4.34 \pm 0.32 a$ & $2.87 \pm 0.18 \mathrm{~b}$ & $4.60 \pm 0.26 a$ & $5.14 \pm 0.26 a$ \\
\hline Ash \% & $1.20 \pm 0.07$ & $1.30 \pm 0.11 \mathrm{a}$ & $1.11 \pm 0.08 a$ & $1.24 \pm 0.13 a$ & $1.09 \pm 0.07 a$ & $1.25 \pm 0.13 a$ \\
\hline
\end{tabular}

Means with different letters within each column for Karadi and Awassi male lambs differ significantly $(\mathrm{P}<0.01)$ according to Duncan's test. 


\subsection{Cost of gain of Awassi and Karadi lambs}

Cost per day, total feed cost and Iraqi dinar $/ 1 \mathrm{~kg}$ weight gain for Awassi lambs was averaged $\quad(385 \pm 10.84, \quad 36,201 \pm 5.26$ and $1,814 \pm 0.11$ ID), respectively and for Karadi lambs averaged $(408 \pm 15.57,38,954 \pm 6.84$ and $2,031 \pm 0.15$ ID), respectively (Table 8). Comparison between the two studied breeds reveals that none significant differences observed in these traits between two breeds, except that for Karadi lambs significantly had a higher Iraq dinar $/ 1 \mathrm{~kg}$ weight gain $(\mathrm{p}<0.01)$ as compared to Awassi lambs.

The lambs slaughtered at $40 \mathrm{~kg}$ significantly had a higher $(423 \pm 14.80$ ID) cost per day $(\mathrm{p}<0.01)$ compared to lambs slaughtered at $50 \mathrm{~kg}$ (371 \pm 22.12 ID), while there were no significant differences between lambs slaughtered at $40 \mathrm{~kg}$ and $30 \mathrm{~kg}(394 \pm 5.78 \mathrm{ID})$. The total feed cost for lambs increased with increasing slaughter body weight from 30 to $50 \mathrm{~kg}(12,665 \pm 0.62$, and $12,944 \pm 0.34$ ID), respectively. The lambs slaughtered at $40 \mathrm{~kg}(2.235 \pm 0.13)$ and $50 \mathrm{~kg}$ $(2.201 \pm 0.08)$ significantly had a higher Iraqi dinar $/ 1 \mathrm{~kg}$ weight gain compared to lambs slaughtered at $30 \mathrm{~kg}(1.368 \pm 0.03)$ (Table 8$)$

In the same trend, Held (1999) concluded that as lambs increase in weight, the cost of gaining weight tends to increase. The lowest cost of gain is commonly during the early growth period when the lamb is lighter and thinner. Excitingly, the lowest price of weight gain during the finishing period occurred at or before the maximum average daily weight gain. In addition, he clarified that when lambs get heaver it requir more feed to gain pound of body weight since the gain includes more fat tissue and less lean tissue than at a lighter less mature status of growth.

Table (8): Cost of gain of Karadi and Awassi lambs (Means \pm S.E.).

\begin{tabular}{|c|c|c|c|c|c|c|}
\hline \multirow[t]{2}{*}{ Traits } & \multirow{2}{*}{$\begin{array}{l}\text { Overall } \\
\text { mean }\end{array}$} & \multicolumn{2}{|l|}{ Breed } & \multicolumn{3}{|c|}{ Slaughter weight (kg) } \\
\hline & & Karadi & Awassi & 30 & 40 & 50 \\
\hline Animal No. & 28 & 13 & 15 & 10 & 9 & 9 \\
\hline $\begin{array}{l}\text { Ration cost } \\
\text { (ID /kg Feed) }\end{array}$ & 391 & 391 & 391 & 391 & 391 & 391 \\
\hline $\begin{array}{l}\text { Daily feed intake } \\
\text { (kg/day) }\end{array}$ & $1.011 \pm 0.02$ & $1.043 \pm 0.04 a$ & $0.984 \pm 0.03 a$ & $1.006 \pm 0.01 \mathrm{ba}$ & $1.081 \pm 0.04 a$ & $0.948 \pm 0.06 b$ \\
\hline $\begin{array}{l}{ }^{*} \text { Cost per day } \\
\text { (ID) }\end{array}$ & $395.5 \pm 9.36$ & $408 \pm 15.57 a$ & $385 \pm 10.84 a$ & $394 \pm 5.78 a b$ & $423 \pm 14.80 \mathrm{a}$ & $371 \pm 22.12 b$ \\
\hline Total feed intake $(\mathrm{kg})$ & $95.85 \pm 10.67$ & $99.63 \pm 17.49 a$ & $92.59 \pm 13.46 a$ & $32.39 \pm 0.50 \mathrm{c}$ & $98.44 \pm 4.54 b$ & $163.78 \pm 6.19 a$ \\
\hline **Total feed cost (ID) & $37.48 \pm 4.17$ & $38,954 \pm 6.84 a$ & $36,201 \pm 5.26 a$ & $12,665 \pm 0.62 c$ & $38,492 \pm 1.78 b$ & $64,037 \pm 2.42 a$ \\
\hline Total weight gain $(\mathrm{kg})$ & $17.85 \pm 1.49$ & $17.43 \pm 2.27 a$ & $18.22 \pm 2.03 a$ & $9.09 \pm 0.23 c$ & $17.64 \pm 0.39 b$ & $27.77 \pm 0.34 a$ \\
\hline${ }^{* * *} I D / 1 \mathrm{~kg}$ wt. Gain & $1.914 \pm 0.09$ & $2,031 \pm 0.15 a$ & $1,814 \pm 0.11 b$ & $1,368 \pm 0.035 b$ & $2,235 \pm 0.13 a$ & $2,201 \pm 0.08 a$ \\
\hline
\end{tabular}

Means with different letters within each column for Karadi and Awassi male lambs differ significantly $(\mathrm{P}<0.01)$ according to Duncan's test

* cost per day (kg/day) =Ration cost (ID/kg feed) X Daily feed intake ( $\mathrm{kg} /$ day)

$* *$ Total feed cost $(\mathrm{ID})=$ Ration cost $(\mathrm{ID} / \mathrm{kg}$ feed $) \mathrm{X}$ Total feed intake $(\mathrm{kg})$

$* * *$ ID $/ 1 \mathrm{~kg}$ wt.Gain $=$ Total feed cost (ID) $/$ Total weight gain $(\mathrm{kg})$

\section{CONCLUSION}

It can be concluded that differences in growth performance, carcass characteristics, carcass tissue distribution, total body fat and total feed cost between two studied breeds exist. Also, total feed intake, feed conversion ratio, fat percentage, total feed cost increased and daily gain in weight, lean percentage, Lean: bone ratio, lean: fat ratio decreased when the slaughter weight was over $40 \mathrm{~kg}$. Therefore the optimal slaughter weight is $40 \mathrm{~kg}$ for both Awassi and
Karadi male lambs. The cost of gain of Awassi lambs was lower than Karadi lambs and from economic trends lambs slaughtered at $30 \mathrm{~kg}$ had higher profit potential.

\section{REFERENCES}

Abdullah, A. Y., and Qudsieh, R. I. (2008). Carcass characteristics of Awassi ram lambs slaughtered at different weights. Livestock Science, 117(2-3), 165-175.

Aksoy, A. R. (1995). Farkli kesim a\$irliklarinda Morkaraman ve Tuj erkek kuzularinin besi 
performansi, kesim ve karkas 62;llikleri. Ankara Univ. Vet. Fak. Derg..42: 1523.(Citedby Balci and KarakaS,2007).

Aksoy, Y., and Ulutaş, Z. (2015). Effect of different slaughter weights on the slaughter and carcass traits of male Karayaka lambs reared under intensive production system. Turkish Journal of Agriculture-Food Science and Technology, 3(6), 406-412.

Al-Jaryan, L. J. A., Alkass, J. E., and Juma, K. H., (1995), "Slaughter weight, feeding level and their relation to some fattening and carcass characteristics in Awassi lambs, BEASTCD, 1989-8/98, AN, 971412932.

Alkass, J. E., and Juma, K. H., (2005), "Small Ruminant Breeds of Iraq, In: Characterization of Small Ruminant Breeds in West Asia and North Africa”, (Luis Iniquezeded) Vol. 1, West Asia, International Center for Agricultural Research in the Dry Areas (ICARDA), Aleppo, Syria, 63-101.

Alkass, J. E., Juma, K. H., and Aldoori, T. S., (1985), "Studies on some economic characteristic in Awassi and Arabi sheep, II. Some fattening and carcass traits", Wld. Rev. Anim. Prod., XXI, 61-64.

Alkass, J. E., Tahir, M. A., Alrawi, A. A., and Badawi, F. S., (1987), "Performance of crossbred lambs raised under two different feeding regimes", Wld. Rev. Anim. Prod. , XXIII, 21-25.

AOAC (1990) Official methods of analysis of the Association of Official Analytical Chemists. 2 vols. 15th ed. Washington, DC.

Balci, F., and Karakaş, E. (2007). The effect of different slaughter weights on the fattening performance, slaughter and carcass characteristics of male Karayaka lambs. Turkish Journal of Veterinary and Animal Sciences, 31(1), 25-31.

Bicer, O., Güney, O., and Pekel, E. (1995). Effect of slaughter weight on carcass characteristics of Awassi male lambs. Journal of Applied Animal Research, 8(1), 85-90.

Cameron, M. R., Luo, J., Sahlu, T., Hart, S. P., Coleman, S. W., and Goetsch, A. L. (2001). Growth and slaughter traits of Boer× Spanish, Boer× Angora, and Spanish goats consuming a concentrate-based diet. Journal of Animal Science, 79(6), 1423-1430.

Chant, J.L. (1977). The effects of sex, energy level and weight on growth, composition and quality of lamb. Dissert. Abs. Int., B. 38: 2445.

Cloete, J. J. E., Hoffman, L. C., Cloete, S. W. P., and Fourie, J. E. (2004). A comparison between the body composition, carcass characteristics and retail cuts of South African Mutton Merino and Dormer sheepe/p. South African Journal of Animal Science, 34(1), 44-51.
Dancun, D.B.(1955). Multiple Range and Multiple F. Test, Biometric. 11: 1- 42.

Das, A. K., Das, G., and Singh, N. P. (2008). Growth, carcass characteristics and meat quality of Muzaffarnagari lambs at various stages under intensive and semi-intensive management. Indian J. Anim. Sci, 78(5), 541-546.

Dosky, K. N., Sulaiman, N. H., and Hidayet, H. M. (2014). Fattening and some carcass characteristics of Karadi lambs raised on concentrate or pasture. J. Biol. Agric. Healthcare, 4(11), 1-4.

Esenbuga, N., Macit, M., Karaoglu, M., Aksakal, V., Aksu, M. I., Yoruk, M. A., and Gul, M. (2009). Effect of breed on fattening performance, slaughter and meat quality characteristics of Awassi and Morkaraman lambs. Livestock Science, 123(2-3), 255-260.

Fahmy, M. H. (1997). Carcass composition in Romanov and crossbred male lambs from 10 to 34 weeks of age and its association with testosterone concentration. Small ruminant research, 26(3), 267-276.

Fahmy, M.H., Shrestha, J.N.B., (2001). Sheep breeds. In: Roginski, Fox, Fuquay (Eds.), Encyclopaedia of Dairy Sciences (Sheep Breeds). Academic Press, UK, pp. 598-612, 2002.

Fuquay, J. W., McSweeney, P. L., and Fox, P. F. (2011). Encyclopedia of dairy sciences. Academic Press.

Gizaw, S., Komen, H., van Arendonk, J.A.M., (2010). Participatory definition of breeding objectives and selection indexes for sheep breeding in traditional systems. Livestock Science 128, 67-74.

Gohler, H. (1989). Fattening performance and carcass composition of lambs fattened to different weights. Tierzucht, 43(7), 308-309.

Gootwine, E., Bor, A., Braw-Tal, R., \& Zenou, A. (1993). Inheritance of birthweight and growth traits in crosses between the Booroola Merino and Assaf sheep breeds. Livestock Production Science, 33(1-2), 119-126.

Gürsoy, O., (2005). Small ruminant breeds of Turkey. In: Iniguez, L. (Ed.), Characterization of Small Ruminant Breeds in West Asia, North Africa, vol. 1, West Asia, ICARDA, Aleppo, Syria, pp. 239-416.

Gürsoy, O., Pekel, E., Özcan, L., Torun, O., and Timon, V. (1993). Comparisons of production traits of Ceylanpınar Awassi sheep with top producing ewes of national flocks in the GAP area. II. Growh performance, carcass traits. Doğa Tr. J. Vet. Anim. SCi, 17(1), 6572.

Gürsoy, O., Pekel, E., Özcan, L., Torun, O., Timon, V., (1992). Genetic selection for milk yield in Awassi sheep. I. Reproduction, lactation. 


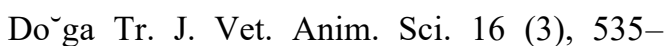
546.7(2), 173-188.

Gürsu, G., and Aygün, T. (2014). Some characteristics of milk yield in Awassi ewes maintained at village conditions. Journal of Advanced Agricultural Technologies Vol, 1(1).

Hailat, N., (2005). Small ruminant breeds of Jordan. In: Iniguez, L. (Ed.), Characterization of Small Ruminant Breeds in West Asia, North Africa, vol. 1. West Asia, ICARDA, Aleppo, Syria, pp. $30-61$.

Hale, D. S., and Griffin, D. B. (1992). Merchandising the meat from goats: Palatability, cutability, and nutrient profile. In proc. Int. conf. on Meat Goat Production, Management and Marketing. Texas Agric. Exp. Sta., Texas AandM University, College station (pp. 76-84).

Hashem, A. L. S., Shaker, Y. M., Abdel-Fattah, M. S., and Ellamei, A. Z. (2013). Effect of weaning age on growth performance and carcass traits of Barki lambs in Siwa Oasis, Egypt. World Applied Sciences Journal, 21(7), 975-982.

Held, J. (1999). Lamb Growth Efficiency and Optimum Finished Weight. Animal Sceince, Report South Dakota, State University.

Hopkins, D. L., and Fogarty, N. M. (1998). Diverse lamb genotypes-1. Yield of saleable cuts and meat in the carcass and the prediction of yield. Meat Science, 49(4), 459-475.

Jawasreh, K. I., Al-Amareen, A. H., and Aad, P. Y. (2019). Growth performance and meat characteristics of the first filial AwassiRambouillet callipyge ram lambs. Veterinary World, 12(6), 783.

Jeremiah, L.E., Jones, S.D.M., Tong, A.K.W., Robertson, W.M., Gibson, L.L. (1997). The influence of lamb chronological age, slaughter weight and gender on yield and cutability. Sheep Goat Res. J. 13: 39-49.

Juma, K. H, and Alkass, J. E., (2000), "Sheep in Iraq", ACSAD, AS, P232, 2000, ACSAD, Damascus, Syria.

Kashan, N. E. J., Azar, G. M., Afzalzadeh, A., and Salehi, A. (2005). Growth performance and carcass quality of fattening lambs from fattailed and tailed sheep breeds. Small Ruminant Research, 60(3), 267-271.

Kemp, J. D., Mahyuddin, M., Ely, D. G., Fox, J. D., and Moody, W. C. (1981). Effect ol t'eeding systems, siaughter weight and sex on organoleptic propefties and thtty acid conrposition of lamb. J. Anim. Sci. 51:321.(Abstr).

Lambuth, T. R., Kemp, J. D., and Glimp, H. A. (1970). Effect of rate of gain and slaughter weight on lamb carcass composition. Journal of Animal Science, 30(1), 27-35.

Lloyd, W. R., Slyter, A. L., and Costello, W. J. (1980). Effect of breed, sex and final weight on feedlot performance, carcass characteristics and meat palatability of lambs. Journal of Animal Science, 51(2), 316-320.

Macit, M., Esenbuga, N., and Karaoglu, M. (2002). Growth performance and carcass characteristics of Awassi, Morkaraman and Tushin lambs grazed on pasture and supported with concentrate. Small Ruminant

Mason, I. L. (1967). Sheep breeds of the Mediterranean. Sheep breeds of the Mediterranean.

Mtimet, N., Baker, D., Audho, J., Oyieng, E., Ojango, J., (2014). Assessing Sheep Traders' Preferences in Kenya: A Best-worst Experiment from Kajiado County.Procedia 1, 63-73.

Nakev, S., Marinova, P., Boikovski, S., and Grigorov, I. (1987). Fattening performance of lambs fattened to different slaughter weights 3. Caucasian sheep in Bulgaria. BEASTCD, 1973, 1982.

Official Iraq Ministry of Agriculture. (2009). Persistent Animal Feed Shortage Taxes Livestock Producers, Baghdad, Iraq. USDA foreign agriculture services.

Oramari, R. A., Alkass, J. E., and Mahmud, K. I. (2014). A comparative study on growth, carcass traits and tissue distribution of Awassi and Hamdani lambs. J. Biol. Agri. And Heal, 4, 36-43.

Pálsson, H., and Verges, J. B. (1952). Effects of the plane of nutrition on growth and the development of carcass quality in lambs part I. The effects of high and low planes of nutrition at different ages. The Journal of Agricultural Science, 42(1-2), 1-92.

Polidori, P., Pucciarelli, S., Cammertoni, N., Polzonetti, V., and Vincenzetti, S. (2017). The effects of slaughter age on carcass and meat quality of Fabrianese lambs. Small Ruminant Research, 155, 12-15.

Prasad, V. S. S., \& Sinha, N. K. (1992). Carcass and non-carcass traits of Muzaffarnagri lambs at different maturity levels. Indian Journal of Animal Sciences, 62(2), 159-164.

Rajkumar, V., and Agnihotri, M. K. (2005). Carcass and meat quality attributes of Muzaffarnagari lambs reared under intensive and semiintensive management system. Indian Journal of Animal Sciences, 75(10), 1196.

Rajkumar, V., Dass, G., Verma, A. K., and Das, A. K. (2014). Slaughter weight effect on carcass and meat quality of Muzaffarnagari lambs in intensive production system. Indian J. Anim. Sci, 84(5), 569-574.

Rashid, N. H., Alkass, J. E., Aldorri, A. A., and Alwan, L. H., (1987), "Growth rate, offals and carcass characteristics of Awassi lambs slaughtered at different weights", J. Agric. 
Water Reso. Res., 6, 27-40.Research, 44(3), 241-246.

Ríos, F. G., Gómez-Vázquez, A., Pinos-Rodríguez, J. M., García-López, J. C., Estrada-Angulo, A., Hernández-Bautista, J., and Portillo, J. J. (2011). Effect of breed on performance and carcass characteristics of Mexican hair sheep. South African Journal of Animal Science, 41(3), 276-279.

Rodríguez, A. B., Bodas, R., Landa, R., LópezCampos, Ó., Mantecón, A. R., and Giráldez, F. J. (2011). Animal performance, carcass traits and meat characteristics of Assaf and Merinox Assaf growing lambs. Livestock Science, 138(1-3), 13-19.

SAS/ STAT. (2002). User's Guide for Personal Computers. Release 6.12 SAS. Institute Inc., Cary, NC.U.S.A.

Sefdeen, S. M., and Alkass, J. E. (2009). Effect of castration and slaughter weight on some fattening performance and carcass characteristics of Karadi lambs. J. Duhok Univ, 12, 95-101.

Sen, A. R., Santra, A., \& Karim, S. A. (2004). Carcass yield, composition and meat quality attributes of sheep and goat under semiarid conditions. Meat science, 66(4), 757-763.
Sents, A. E., Walters, L. E., and Whiteman, J. V. (1982). Performance and carcass characteristics of ram lambs slaughtered at different weights. Journal of Animal Science, 55(6), 1360-1369.

Shelton, M., and Carpenter, Z. L. (1972). Influence of sex, stilbestrol treatment and slaughter weight on performance and carcass traits of slaughter lambs. Journal of Animal Science, 34(2), 203207.

Shukor, E. V. (1989). A comparative study for some growth characteristics of Karadi and Hamdani sheep. MS. thesis. College of agriculture and forestry. University of Mosul. in Arabic

Snowder, G. D., Glimp, H. A., and Field, R. A. (1994). Carcass characteristics and optimal slaughter weights in four breeds of sheep. Journal of Animal Science, 72(4), 932937.

Suliman, G. M., Al-Owaimer, A. N., El-Waziry, A. M., Hussein, E. O. S., Abuelfatah, K., and Swelum, A. A. (2021). A Comparative Study of Sheep Breeds: Fattening Performance, Carcass Characteristics, Meat Chemical Composition and Quality Attributes. Frontiers in Veterinary Science, 8. 